\title{
The Rancher's Dilemma: A Game Exploring the Implications of an Open Access System
}

\author{
Julia Frost Nerbonne*
}

\begin{abstract}
The Rancher's Dilemma is a game developed to allow high school, college and adult students to experience problems associated with open access resources. Adapted from Garret Hardin's The Tragedy of the Commons, the game allows students to play the role of a rational and self-interested rancher experiencing the demise of a common resource due to lack of regulation or management. As a follow-up to the game, students are encouraged to think about the role of regulation and community management in maintaining a commons. A classroom trial of the game was conducted with three groups of college students who were taking a course on environmental ethics and conflict management. Student reflections help to illustrate how this game can be used as a basis for discussion on how individual self interest can destroy a common pool resource, and how collective management can aid in creating sustainable commons.
\end{abstract}

\section{Freedom in the commons brings ruin to all.}

Garret Hardin (1968)

$\mathbf{I}_{\mathrm{a} a t y}^{\mathrm{N}}$ an age of global commons, reflection on how to sustainably use and manage community resources is a critical component of a full education in natural resource science or agronomy. In this paper I describe a game in which students experience, first hand, the tragedy that ensues when a common pool resource is left unmanaged. Putting themselves in the position of a rational, self-interested rancher, they experience both individual gain, and ultimately group loss, as the commons becomes destroyed by unrestricted use. Through communication with other students they are invited to explore the need for community leadership as they come to realize the danger of an open access system. In 1968 Garret Hardin wrote, The Tragedy of the Commons, in which he illustrates how rational self-interest can lead to the demise of common resources (Hardin, 1968). In this parable, rational self-interest drives herdsmen to increase the size of their herd without regard to the negative impact on commonly owned land. Each individual stands to gain more by adding one more animal to their own herd (+1) than they stand to lose (a fraction of -1 ) (Berkes, 1996). Collectively, this practice leads to overgrazing, and ultimately to exceeding the carrying capacity of the common pasture. While individual graziers may recognize the impending failure of the pasture, they have no control over the actions of others, and thus resort to choosing the less sustainable and selfish option.

During the 1990s a great deal of attention was given to redefining the concept of common property (Burger and

Department of Fisheries Wildlife and Conservation Biology, Univ. of Minnesota, 200 Hodson Hall, 1980 Folwell Ave., St. Paul, MN 55108. Received 5 July 2002. *Corresponding author (jaf@ fw.umn.edu).

Published in J. Nat. Resour. Life Sci. Educ. 32:65-68 (2003). http://www.JNRLSE.org

(C) American Society of Agronomy

677 S. Segoe Rd., Madison, WI 53711 USA
Gochfeld, 1998). With respect to land ownership, Ostrom (1990) defines four different property rights regimes — open access, state property, common property, and private property.

Hardin's system, in which individuals act without reference to or communication with others, is called an open access system. In an open access system anyone has the right to utilize the resource, and there are no associated duties connected to that privilege.

State property is another form of commonly owned land. In this case citizenship defines ownership, and the land is managed by the state in an effort to maintain the social objectives of the citizenry. Because all citizens have ownership, a small group cannot exclude the access of others; however, statemandated regulation can control how the land is used.

Alternately, property can be owned and governed by a collective in a regime called common property. In this scenario, property is collectively owned and governed by a select group. Those not part of the collective are excluded from access. Those included in the collective are responsible for maintaining the property according to the rules established by the collective.

Private property assigns ownership to an individual. While required to maintain socially acceptable use of their land, the property owner controls access to the property (Ostrom, 1990; Hanna et al., 1996; Burger and Gochfeld, 1998). Pollution of air or water quality on a privately owned property can influence the collective well being; thus, commons can also refer to other resources such as air and water that are collectively used.

Biologists have illustrated that if a natural system is used by humans at low levels of intensity, it can maintain a balanced and stable state for long periods of time. However, if the resources are over-exploited, the system can flip into an alternative, often less productive, state (Holling, 1995; Holling and Sanderson, 1996). Once a system has been overexploited, returning to the previous state can be difficult. For example, if a grassland is overgrazed, erosion can occur, washing away productive topsoil. Once this topsoil is removed, production of grass will decrease indefinitely and the system can become dominated by less productive forage for livestock. For example sagebrush (Artemisia tridentata Nutt.) may invade under these conditions in the arid regions of the western USA. Under more humid conditions, such as in the Great Plains states, invasive species such as leafy spurge (Euphorbia esula L.), musk thistle (Carduus nutans L.), or a number of woody species will encroach.

For humans to make sustainable land management decisions, they must rely on feedback from the land. Overgrazing results in poor-quality forage, which leads to decreased yields. If social mechanisms allow, this knowledge should lead the rancher, or community of ranchers, to change management strategies. This can be challenging, however, because complex ecosystems are variable and uncertain, changing at a variety of different spatial and temporal scales. Even in the best of cir- 
Table 1. Set-up of participant score card.

\begin{tabular}{|c|c|c|c|c|c|c|}
\hline & $\underline{\text { Initial bank balance } \dagger}$ & $\begin{array}{c}\text { Units of money spent } \\
\text { on cows at the start } \\
\text { of the season } \\
\end{array}$ & $\begin{array}{c}\text { Units of money } \\
\text { earned from } \\
\text { fattened cattle }\end{array}$ & $\begin{array}{c}\text { End of year } \\
\text { balance }\end{array}$ & & No. of total \\
\hline Year & $Z_{1}$ & $-X$ & $+(X \times Y)$ & $\mathrm{Z}_{2}$ & Weather & cattle grazed \\
\hline 1 & Dependent on group size & & & & & \\
\hline 2 & & & & & & \\
\hline 3 & & & & & & \\
\hline 4 & & & & & & \\
\hline 5 & & & & & & \\
\hline 6 & & & & & & \\
\hline 7 & & & & & & \\
\hline
\end{tabular}

$\dagger$ Initial bank account value $=1000 \div$ number of participants, rounded to the nearest whole number.

Table 2. Example score card.

\begin{tabular}{|c|c|c|c|c|c|c|}
\hline \multirow{2}{*}{$\begin{array}{c}\text { Weather } \\
\text { (drawn from a hat: } \\
\text { poor, fair or good) }\end{array}$} & \multirow{2}{*}{$\begin{array}{l}\text { No. of total cattle } \\
\text { grazed (total of all } \\
\text { game participants) }\end{array}$} & \multirow[b]{2}{*}{ Year } & \multirow{2}{*}{$\begin{array}{c}\begin{array}{c}\text { Initial bank balance } \\
(\text { Year } 1=10 ; \text { or end of } \\
\text { previous year balance) }\end{array} \\
Z_{1}\end{array}$} & \multirow{2}{*}{$\begin{array}{c}\begin{array}{c}\text { Units spent on } \\
\text { feeder cattle }\end{array} \\
-X\end{array}$} & \multirow{2}{*}{$\begin{array}{l}\text { Units earned from fattened } \\
\text { cattle }(Y \text { is announced } \\
\text { by instructor })\end{array}$} & \multirow{2}{*}{$\begin{array}{c}\begin{array}{c}\text { End of year } \\
\text { balance }\end{array} \\
Z_{2}\end{array}$} \\
\hline & & & & & & \\
\hline Poor & 250 & 1 & 10 & -5 & $+(5 \times 0.5)$ & $=7.5$ \\
\hline Good & 140 & 2 & 7.5 & -2 & $+(2 \times 2)$ & $=9.5$ \\
\hline Fair & 190 & 3 & 9.5 & -5 & $+(5 \times 1)$ & $=9.5$ \\
\hline
\end{tabular}

cumstances feedback loops are not always clear and can take considerable time and effort to understand. As a human society we must understand the complexities of natural systems and build institutions that allow management of the commons in a way that recognizes the good of the whole.

In this game, participants experience first hand what Hardin describes as a rational drive to exploit an open access system. Participants then have an opportunity to explore management options under different property regimes, working together to create rules for sustainable management of complex and uncertain ecosystems.

\section{PLAYING THE GAME}

This game should be conducted with 10 to 100 participants. The objective is to simulate an open access system in which students, posing as farmers, graze cattle on public land. Each year participants purchase a selected number of cows with money they have from a bank account. The initial bank balance is $Z$ and the number of cattle purchased is $X$ (Table 1). At the end of the season they sell the fattened cattle back to the market. They then receive a sum for each of the cattle (Tables 1 and 2 ). The amount a participant should receive $(Y)$ for each head $(X)$, is reported by the instructor at the end of each round (or year). Table 3 will lead you through this calculation. The amount a participant should receive, $Y$, which determines the market price for the cattle, is a function of both the weather and the total number of cattle using the common pasture; $Y$ should be determined by referring to Table 3 . If the weather is bad and the cattle overgraze the land, participants receive only a portion of what they have invested. If the weather is good, and the total number of cattle does not exceed the carrying capacity, they can potentially double their money.

To determine the weather for each round, a student should be chosen to draw a weather card from a hat. The instructor should place an equal number of good-year, fair-year, and badyear cards in the hat. Alternately, the instructor may choose to call out the weather conditions for each round, maintaining more control over the game's outcome. To determine the total number of cattle placed on the pasture each year, participant counters are assigned to collect and tally the number of cattle grazed by each individual each year. In a large group, having multiple counters who can calculate subtotals for a smaller group may be helpful. These subtotals can then be passed over to a central counter, who calculates the total number of cattle grazed in that year. Each participant should record both the weather and the number of cattle on their own game sheet (Table 1).

The beginning balance in each participant's bank account depends on the number of people playing the game. One unit of money is enough to purchase one cow. Make sure that the sum of all bank accounts is approximately 1000. Therefore the beginning balance for each participant will be 1000 divided by the number of participants and rounded to the nearest whole number. For example, if there are 100 participants, each should receive 10 units of money; alternatively, if there are 10 students present, each should receive 100 units. Only whole units can be used for play (there is no such thing as a live half cow).

At the end of each round, the instructor should use Table 3 A to determine $Y$. If the number of cattle exceeds 200 for five consecutive rounds, he or she can then switch to Table $3 \mathrm{~B}$, or remain with Table 3A. Table 3B should be used with more advanced students to illustrate how an ecosystem can enter a different stable state after being heavily used. ${ }^{1}$

In a college class of 100 , playing seven rounds of this game should take approximately $45 \mathrm{~min}$. Instructors are encouraged to allow participants to play the game for one session, during which they are not allowed to communicate with others. When this session is done, participants can collectively

\footnotetext{
${ }^{1}$ Adding this twist to the game is appropriate for lessons in which the instructor is trying to illustrate the role of uncertainly in natural resource planning. Students should be confused by the switch to Table 3B. Just as students are figuring out the relationship between the number of cattle grazed and market prices at the end of the year, the system flips. This is the type of uncertainty that resource managers deal with every day, and can lead to fruitful discussions about the need for adaptive management and monitoring.
} 
Table 3A. The instructor should use this chart to determine the value of $Y$ until there has been five consecutive years of over-grazing (Total $X$ $>200$ ).

\begin{tabular}{cccc}
\hline & \multicolumn{3}{c}{ Weather } \\
\cline { 2 - 4 } No. of total cattle & Good & Fair & Poor \\
\hline$<150$ & 2 & 1.5 & 1 \\
$150-250$ & 1.5 & 1 & 0.5 \\
$>250$ & 1 & 0.5 & 0 \\
\hline
\end{tabular}

reflect on problems associated with open access. If time permits, they should play a second time. This time they should be encouraged to develop community regulation, working together to increase their collective success. Their ability to succeed at self-regulating can highlight the benefits and the struggles associated with a true common property regime vs. state or private property.

Scenario: Read This to the Class/Participants. Imagine that you reside in a community of ranchers. You have saved a pool of money to invest in cattle that you will graze on public land. Each year you will decide how many cows to purchase, you will buy them through the bank, and you will place them on the public land. When you have decided how many cows you will be grazing, write the number on a piece of scrap paper and pass it down to one of the assigned counters. After 6 months you will remove the cattle from the public land and sell them on the market. Once all the ranchers have brought their cattle to market you will be paid for your cattle. Meanwhile, you will learn something about the weather when one participant randomly draws a weather card from a hat, indicating that it has been a good, fair, or bad year. You will also be informed (by the counters) how many total cattle were grazed that season. Each participant should set up a game table as seen in Table 1.

\section{CLASSROOM TRIAL}

A classroom trial of The Rancher's Dilemma was conducted in an upper-level undergraduate course at the University of Minnesota (Ethics, Conflict and Leadership in Natural Resource Management). The course is designed to give students an opportunity to reflect on the current cultural mores that govern human relationships with natural systems. Students in this course are exposed to basic environmental philosophy and conflict management theory, and are then asked to reflect on real-world environmental conflicts. In an attempt to combine ethics and conflict management, the course asks students to reflect on environmental issues using a two-tiered approach: first the students examine fundamental values connected with current issues, and then they look at how realworld conflict management is enacted. The Rancher's Dilemma gives students an opportunity to experience the theoretical perspective embodied by Hardin's The Tragedy of the Commons, and provides an opportunity for them to consider how real world solutions, such as creating community rules, can positively impact natural resources.

Three classes, including a total of more than 200 students, played this game. Before the class session students were assigned to read Hanna et al. (1996), Property Rights and the Natural Environment. In each of the classes, playing seven rounds took between 30 and 45 min. Having well-informed
Table 3B. The instructor can use this optional chart to simulate a flip in the system after 5 consecutive years of overgrazing (Total $X>200$ ).

\begin{tabular}{cccc}
\hline & \multicolumn{3}{c}{ Weather } \\
\cline { 2 - 4 } No. of total cattle & Good & Fair & Poor \\
\hline$<150$ & 1 & 0.5 & 0 \\
$150-250$ & 0.5 & 0.5 & 0 \\
$>250$ & 0.5 & 0 & 0 \\
\hline
\end{tabular}

helpers to guide student counters and to help individual students fill in their participant score cards (see Table 1) was helpful. Passing out a copy of the score card, and using an overhead projector to model the way that students fill in the score card was beneficial.

After the first session, in which participants played without organized communication among themselves, students were asked to complete a written reflection on (i) decisionmaking strategies that they employed during the game, and (ii) how this game related to the concepts of open access vs. common property as described above.

In each of the three game sessions, weather cards were selected at random, leading to a slightly different result with each group. During the first two games, the weather was good or fair for the majority of the game. During the third game, weather was poor or fair for the first four rounds.

Students responded, almost across the board, that they enjoyed the game. The game provided a welcome break to class discussion and lecture, and taught them some valuable lessons. As one student stated, "At first I thought the game was kind of goofy. It was not until I stopped to think about it that I realized these were real concerns for certain people every day." They also learned in a tangible way about how the unpredictability of nature can impact human communities.

Reflecting on their own decision-making process, it appears that a few rounds of the game were needed for participants to realize that their decisions were being impacted by those around them. As one participant stated, "I thought it was funny how in the beginning we all bet pretty high because we did not realize how the game worked. Once we figured it out we were not betting so carelessly." Once participants became aware that overgrazing resulted in a loss for all, most became more cautious, but not all: "I was the calculator person. It was very interesting to see how much the numbers increased by just one person going overboard. It was a great example of how you cannot control other people's decisions in an open access situation."

In the third game, in which weather conditions were fair or bad during the first four rounds, students reflected on community regulation more than students from the previous two classes. As students observed, "Positive environmental conditions resulted from self-regulation." and, "I discussed [things] with the participants near me... This communication made it possible to make wiser decisions. Communication made us more aware of each other, and less likely to buy the maximum amount of cows." Even without any official community regulation, many students were placing limits on their use of the pasture.

In this game, participants also did a better job at voluntary self-regulation, but the greedy individuals, although they were not identified, did not go unnoticed. "At first it seemed like everybody in the community had good intentions, but there 
were always a greedy few that ruined the whole thing." Or as another stated, "In my mind [people] viewed the game as an opportunity to win. Instead of viewing winning as a collective feat, they viewed it as individually coming out with the most."

When asked to reflect on open access vs. common property regimes, responses indicated that the game was able to bring clarity to many. "As a group we could have decided what we wanted to accomplish and how, and made an effort to create rules that would go by that ethic." And, "I can envision a set of communal rules that would allow for the maximum production of goods while still allowing for long-term future gains. [In this case] there would be a healthy sustainable environment." Some students offered some workable solutions as well. "Creating a round table discussion might have helped." And, "Rules fill the void between dismissing the needs of our neighbor, and caring. If we must deal with their concerns it is less likely that we will be selfish."

Many also connected the problem with open access to a larger problem with American culture. "It is the American norm to attempt to accumulate as much as possible. People strive to make as much money as they can at any cost, often [turning a blind eye] to what destruction they have caused in the process."

\section{DISCUSSION}

During the $3 \mathrm{yr}$ that this game has been part of my course, I have come to recognize the impact of collaborative learning on the class. Having a concrete example that everyone has been actively engaged in has given me the opportunity to ground new ideas with a tangible common experience. During this classroom exercise students had the opportunity to explore their own response to an open access regime. For many, the experience of letting individual gain bring ruin to a commons helped to clarify the need for leadership and community ethics. Numerous times during the remainder of the course students wove this experience into their analysis of a problem. When discussing the role of state vs. local government, for ex- ample, the class returned to The Rancher's Dilemma to examine how collective responsibility might be best achieved under this type of property rights regime.

The game also served to stimulate challenging questions about feedback loops. How can a rancher tell that land is being over-grazed? How would a centralized authority gain this information? How much risk should a community take? If there is regulation, who will have the authority to punish cheaters? As with most classroom experiences, the questions generated from the game were often more valuable than the answers.

Garret Hardin (1968) uses this example to illustrate what will inevitably happen as the global human population expands. In the context of a modern day ethics, leadership, conflict management, or policy class, the example of the common pasture can take on new meaning. Instead of providing an example of the hopeless flaws of humanity, it can provide concrete experience that provides a springboard for a discussion on viable alternatives such as community regulation and management.

\section{REFERENCES}

Berkes, F. 1996. Social systems, ecological systems, and property rights. p. 87-110. In S. Hanna et al. (ed.) Rights to nature. Island Press, Washington DC.

Burger, J., and M. Gochfeld. 1998. Tragedy of the commons thirty years later. Environment 40(10):4-13; 26-27.

Hanna, S., C. Folke, and K. Maler. 1996. Property rights and the natural environment. p. 1-12. In S. Hanna et al. (ed.) Rights to nature. Island Press, Washington DC.

Hardin, G. 1968. The tragedy of the commons. Science (Washington, DC) 162:1243-1248.

Holling, C.S. 1995. What barriers? What bridges? p. 3-13. In L.H. Gunderson et al. (ed.) Barriers and bridges to the renewal of ecosystems and institutions. Columbia Univ. Press, New York.

Holling, C.S., and S. Sanderson. 1996. Dynamics of (dis)harmony in ecological and social systems. p. 57-86. In S. Hanna et al. (ed.) Rights to nature. Island Press, Washington DC.

Ostrom, E. 1990. Governing the commons: The evolution of institutions for collective action. Cambridge Univ. Press, New York. 